\title{
How the Knowledge of the Major Researchers Is Forging the Business Strategy Paths: Trends and Forecasts from the State of the Art
}

\author{
DOI: 10.12776/QIP.V24I3.1404 \\ Luís C.F.M. Barbosa, Maria A.S. Mathias, Gilberto Santos, \\ Otávio J. de Oliveira
}

Received: 2020-02-21 Accepted: 2020-08-24 Published: 2020-11-30

\begin{abstract}
Purpose: Given its large number of publications, the subject "strategy" stands out as an important field of scientific literature with multidisciplinary characteristics, involving the most varied research areas. The aim of this paper is to analyse the state of the art on business strategy, which have enabled the identification of the characteristics of the most influential articles and authors.
\end{abstract}

Methodology/Approach: This article is a literature review based on bibliometric parameters, which the main novelty has been the identification of specific characteristics of the main publications and researchers on business strategy during the peak production period of 1998-2017.

Findings: The main contribution of this article is to guide researchers interested in developing studies related to business strategy, highlighting the subject's chronological evolution and the correlations analyses among publications.

Research Limitation/Implication: The searches and selection of bibliometric parameters have been limited to two of the most relevant databases (Scopus and Web of Science). Another restriction was that only articles and reviews containing the term "business strategy" in their respective titles were considered.

Originality/Value of paper: Although bibliometric studies have already been published in managerial and strategic areas and subareas, the scientific literature still lacks articles with the same level of details and analysis performed in this paper, which portrays the main novelty of this research.

Category: Literature review

Keywords: strategy; business strategy; bibliometric analysis; state of the art; review 


\section{INTRODUCTION}

Strategy is a word originated from the Greek word strategia, which means plan, method, process, maneuvers, or decisions used to achieve a specific goal or outcome. It has its origin in the military area and referred to "the general art", in which the psychological and behavioural skills of the general of the army concerned the planning and execution of the troops' movements during a conflict (Dalby, 2007; Zott and Amit, 2008; Ghemawat, 2016). In an organisational context, strategy started to stand out in a more effective manner after the Second World War, intensifying after the economic globalisation, creation of several trading blocs, technological progresses, new market demands, and scarce natural resources, compelling organisations to constant operational and managerial changes (de Oliveira, 2013; Araújo et al., 2019; Bravi, Murmura and Santos, 2018; Barbosa, de Oliveira and Santos, 2018; Santos, Murmura and Bravi, 2019; Santos et al., 2014; Costa et al., 2019; Talapatra et al., 2019; Carvalho, Santos and Gonçalves, 2020; Sá et al., 2020).

The elaboration of a business strategy is pivotal for the organisation's planning and success (Rodrigues et al., 2019; Marinho, Silva and Santos,2020; Félix et al., 2019). Therefore, the formulation of the competitive strategy must be adjusted to the environmental conditions surrounding an organisation (Abraham, 2013; Zgodavova and Bober, 2012; Zgodavova et al., 2020). The strategic planning constitutes an administrative effort that, based on the evaluation of the company's condition and environmental situation, results in a critical acknowledgement of its opportunities, threats, strengths and weaknesses to fulfil its mission, establishing structured and formal guidelines to orient the organisation (Agarwal, Grassl and Pahl, 2012; Salavou, 2015; Santos et al., 2019; Bravi, Murmura and Santos, 2019).

The great amount of publications on strategy attests to its relevance to the scientific literature. Strategy-related researches present multidisciplinary features and involve the most varied research areas (Zhuang et al., 2013; Coombes and Nicholson, 2013). These features are even more explicit when searched in the literature using the term "business strategy", be it on the articles title, abstract, keywords, chapter, or congress articles, resulting in 77,498 publications until December 31st, 2017 (Scopus, 2017).

Articles and reviews published in indexed journals ensure greater reliability to the researches (Campanario, 2014). Thus, it has been decided that only the articles' and reviews' titles should be used in the queries for "business strategy" to obtain accurate and academic relevant results.Until December 31st, 2017 there were 2,269 articles in the literature, with the first publications dating back to the end of the 1950's, and an intensification in the production through time (Scopus, 2017; Web of Science, 2017).

Coincidently, the number of publications regarding business strategy started to grow with the beginning of the competition era, by end of the 1970's and beginning of the 1980's (Scopus, 2017; Web of Science, 2017). One of the 
pioneers in introducing this concept to the scientific literature was Michael Porter, whose thinking is based on the importance of the external environment and the positioning of the company in this environment (Magretta, 2012; Tansey, Spillane and Meng, 2014). This fact has also contributed to the increase in the number of publications (Scopus, 2017; Web of Science, 2017). Although bibliometric studies have already been published in managerial and strategic areas and subareas, the scientific literature has not witnessed a study with the same level of details and analysis of this article, which identified the characteristics of the main publications and the major researchers on business strategy during the period of 1998 to 2017 (Agarwal, Grassl and Pahl, 2012; Salavou, 2015).

In light of these arguments and based on the established scientific gap, the research question that guided the development of this article is: how can the bibliometric analysis on business strategy provide a global perspective of the field, thus correlating the existing interactions among the main countries, institutions, journals, articles and authors with the highest impact? Therefore, these bibliometric analyses allowed the identification of the characteristics of the main publications and the major researchers on business strategy in the scientific literature, which stands as this paper's objective and main novelty.

This article is divided into five sections. The first section have presented the introduction and justified the relevance of business strategy, as well as the research question and the article's objective. The second section is composed by the research method, while the third section exposes the results analysis. The main characteristics of the most influential articles and authors related to the theme shall be presented in the fourth section. At last, the paper's conclusion can be found in the fifth section.

\section{METHODOLOGY}

This article is a literature review designed to identify the contributions regarding business strategy through an overarching bibliometric analysis. Literature reviews report the current knowledge about a topic and is based on the summary of researches previously published, providing a comprehensive view of the subject (Garousi and Mäntylä, 2016). Its goal is to keep the reader updated about the latest findings and substantiate the formulation of new proposals, facilitating future researches (Carnwell and Daly, 2001).

Bibliometric studies are used to inquire the standards and trends published about a certain theme, thus, helping explore and organise the state of the art as a whole (Coombes and Nicholson, 2013). The most recent bibliometric analyses have evolved to incorporate interrelations analyses among major authors, institutions and countries, as well as convergence analysis among prominent journals and the most cited articles (Zhuang et al., 2013; Ferreira et al., 2014). 
To conduct an analysis compatible with the purpose of this article, the articles have been searched in both the Scopus and the Web of Science platforms. These databases are able to provide multidisciplinary scientific articles from a wide range of journals of different publishers, guaranteeing the access to a great part of the internationally published literature and allowing the export of metadata for a proper bibliometric analysis (Guerrero-Bote and Moya-Anegón, 2012; Garousi and Mäntylä, 2016).

The types of documents used in this study include only articles and reviews published in internationally indexed journals. In accordance with Salavou (2015), these are the most reliable documents for literature reviews, since they adopt a blind review criteria, thus ensuring a higher reliability. Moreover, only Englishwritten publications were assessed for their global reach (Scopus 2017; Web of Science, 2017). Figure 1 presents the methodological flow and sequence of activities related to the research.

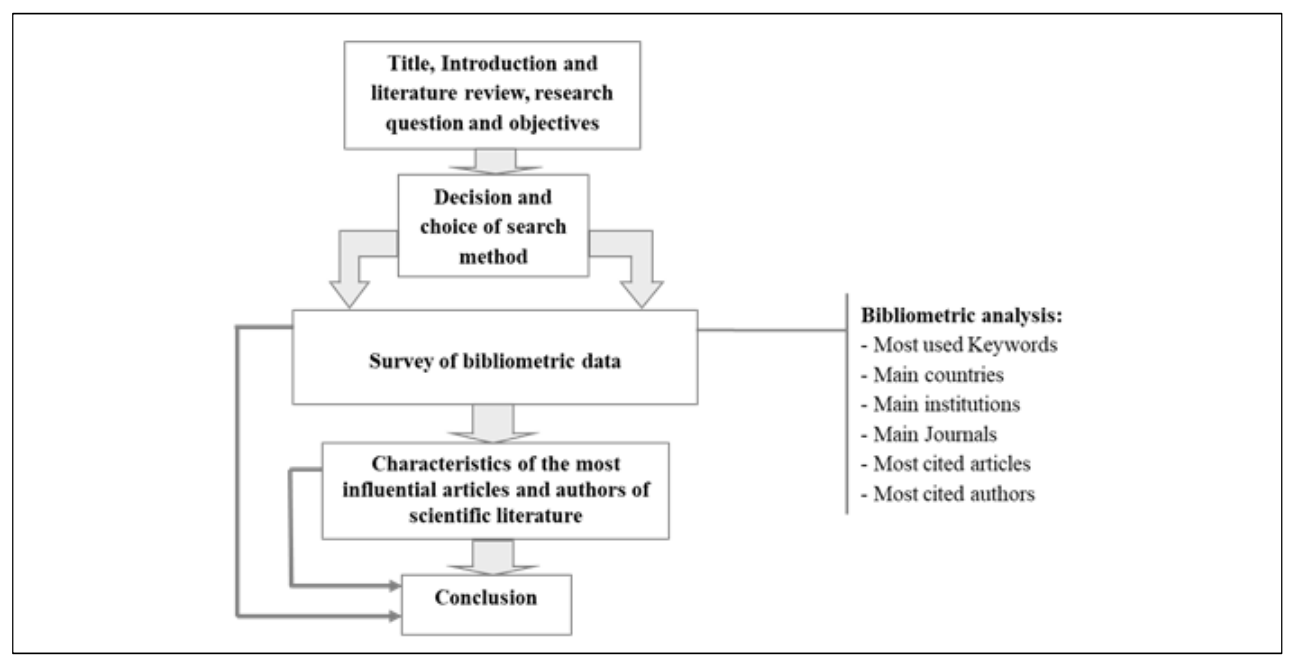

Figure 1 - Research Methodological Flow

This study used basic bibliometric parameters, namely: number of accumulated citations, number of documents and a calculation of the quocient of the citations by the amount of documents, so to avoid past years' measurement of scientific quality based solely on the number of citations (Campanario, 2014). Therefore, this paper's analyses were centered around the publications' total number of citations accumulated in the period $(\mathrm{C})$, the total number of documents in the period $(\mathrm{N})$ and the impact of this publications $(\mathrm{C} / \mathrm{N}=$ number of aggregated citations by the amount of published documents). These parameters reflect the scientific literature published until December 31st, 2017, and were combined to identify the relevance of keywords, countries, institutions, journals, articles and authors. 
It should also be highlighted that the analyses of the main institutions, journals, and most cited articles and authors have taken into account a minumum of five publications related to business strategy. This minimal condition has been applied to exclude institutions, journals, articles and authors with low productivity, despite their respectives high numbers of citations in a sole publication. Regarding the analysis of the most cited articles, it is also possible to identify their corresponding impact factors, which indicate the publications' importance and prestige for a determine field (Chung, 2007; Campanario, 2014).

Microsoft Excel, Microsoft PowerPoint and VOSviewer softwares were employed to develop the tables, graphics, charts and figures necessary to the bibliometric analysis of the collected data from the Scopus and Web of Science databases. Furthermore, the VOSviewer software also allowed the identification of correlation networks among the main countries and authors on business strategy.

\section{FINDINGS}

This article goes beyond the traditional bibliometric analysis commonly found in the scientific literature for this field. External parameters to the publications were considered, among them: international trade relations, human development indexes, participations in trade blocs and international groups, and international competition and innovation rankings (Dutta, Lanvin and Wunsch-Vincent, 2017; Schwab and Sala-i-Martín, 2017). Figure 2 exhibits the subject's keywords and their frequencies in the published papers. Since it is the object of this article, the keyword "business strategy" has not been included in this analysis (Scopus, 2017).

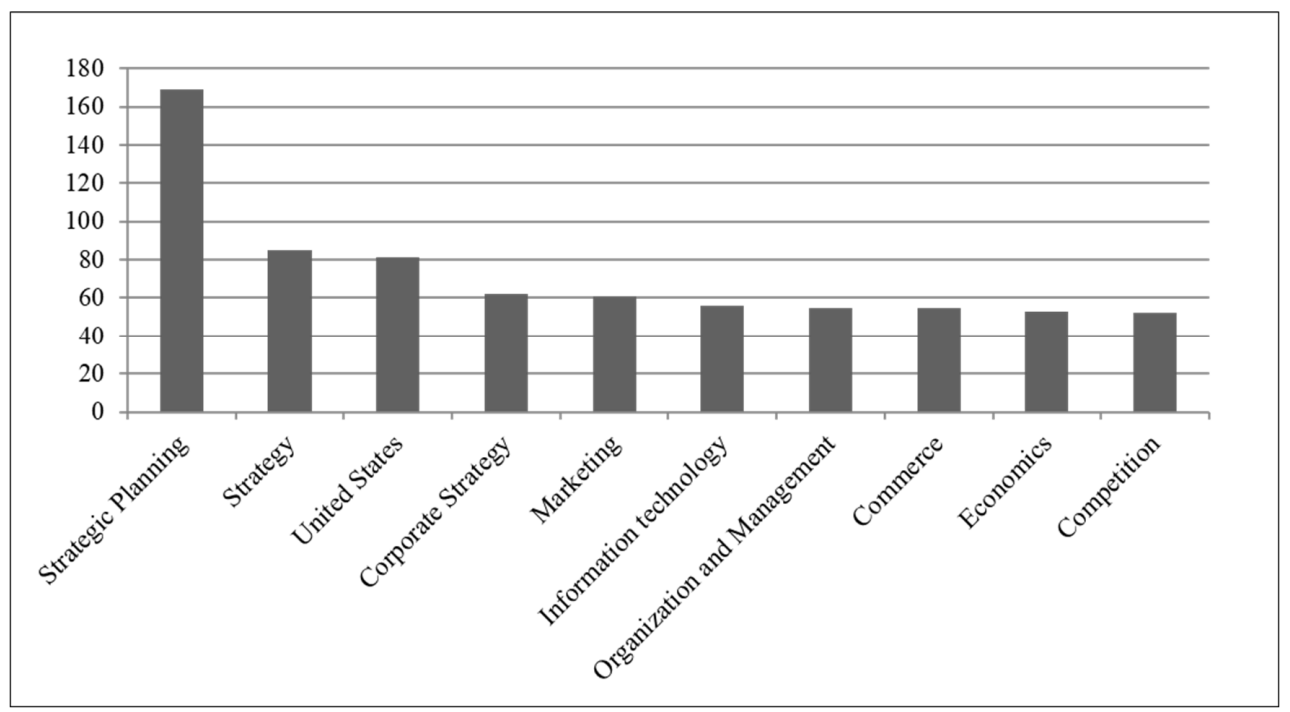

Figure 2 - Most used Keywords in Researches about "Business Strategy" 
Still in Figure 2, it is possible to observe that 9 out of the 10 most cited keywords are directly related to the managerial and strategic areas, except for the keyword "United States". Additionally, Table 1 exposes the countries that publish the most and, thus, stands out in business strategy. The United States and United Kingdom are the two biggest influences on this field, totalling 708 out of the 2,269 articles found, which represent $31.21 \%$ of the total of publications. The United States only are responsible for 500 articles, representing a little more than one fifth or $22.03 \%$ of all the publications (Scopus, 2017).

Table 1 - The Ten Most Influential Countries on "Business Strategy"

\begin{tabular}{|c|l|c|c|c|}
\hline$\#$ & Country & $\begin{array}{r}\text { Accumulated } \\
\text { citations }(C)\end{array}$ & $\begin{array}{c}\text { Number of } \\
\text { documents }(N)\end{array}$ & $\begin{array}{c}\text { Impact } \\
(\text { C/N })\end{array}$ \\
\hline 1 & United States & 17,092 & 500 & 34.2 \\
\hline 2 & United Kingdom & 5,165 & 208 & 24.8 \\
\hline 3 & Canada & 1,930 & 56 & 34.5 \\
\hline 4 & Netherlands & 1,872 & 45 & 41.6 \\
\hline 5 & Germany & 1,744 & 57 & 30.6 \\
\hline 6 & France & 1,216 & 44 & 27.6 \\
\hline 7 & Sweden & 1,071 & 30 & 35.7 \\
\hline 8 & Hong Kong & 1,059 & 21 & 50.4 \\
\hline 9 & Australia & 922 & 68 & 13.6 \\
\hline 10 & Taiwan & 635 & 47 & 13.5 \\
\hline
\end{tabular}

It is important to highlight that, together, the ten most relevant countries add up to 1,076 articles, which represent $47.42 \%$ of the total of publications regarding "business strategy" (Scopus, 2017). It is important to notice that all ten countries mentioned in Table 1 are part of the World Trade Organization, an intergovernmental organisation that regulates and controls the international trade among countries. Moreover, these ten countries present the highest levels of the Human Development Index (HDI), ranging between 0.800 and 1.00 (Dutta, Lanvin and Wunsch-Vincent, 2017; Schwab and Sala-i-Martín, 2017).

Among them, only Taiwan and Hong Kong belong to the list of nations known as G20, a group formed by government representatives of the nineteen biggest world economies, plus the European Union. The G20 represent $80 \%$ of the world trade (including the intra-European trade market), two thirds or $66.67 \%$ of the world population, and $90 \%$ of the world GDP. In this context, the United States stands out again with the biggest world economy, being responsible for a GDP of $\$ 17.95$ trillion, which alone represents almost one fourth or $24.53 \%$ of the world GDP (Dutta, Lanvin and Wunsch-Vincent, 2017; Schwab and Sala-i-Martín, 2017). United States, United Kingdom, Germany, Canada and France integrate 
the G7, which is the group of the seven biggest world economies as per the International Monetary Fund (Dutta, Lanvin and Wunsch-Vincent, 2017; Schwab and Sala-i-Martín, 2017).

All of the ten cited countries in Table 1 are among the 25 leading nations in terms of competition index (Schwab and Sala-i-Martín, 2017). The competition index is an increasing trend relevant to the organisations with regard to the structure of their business strategies, since it indicates their main weaknesses, as well as their best opportunities, taking into account their strengthens and features (Tansey, Spillane and Meng, 2014). In order to highlight the importance of those ten countries in Table 1, Figure 3 displays the correlation network of the most influential countries to the theme in which the same ten countries previously analysed are present.

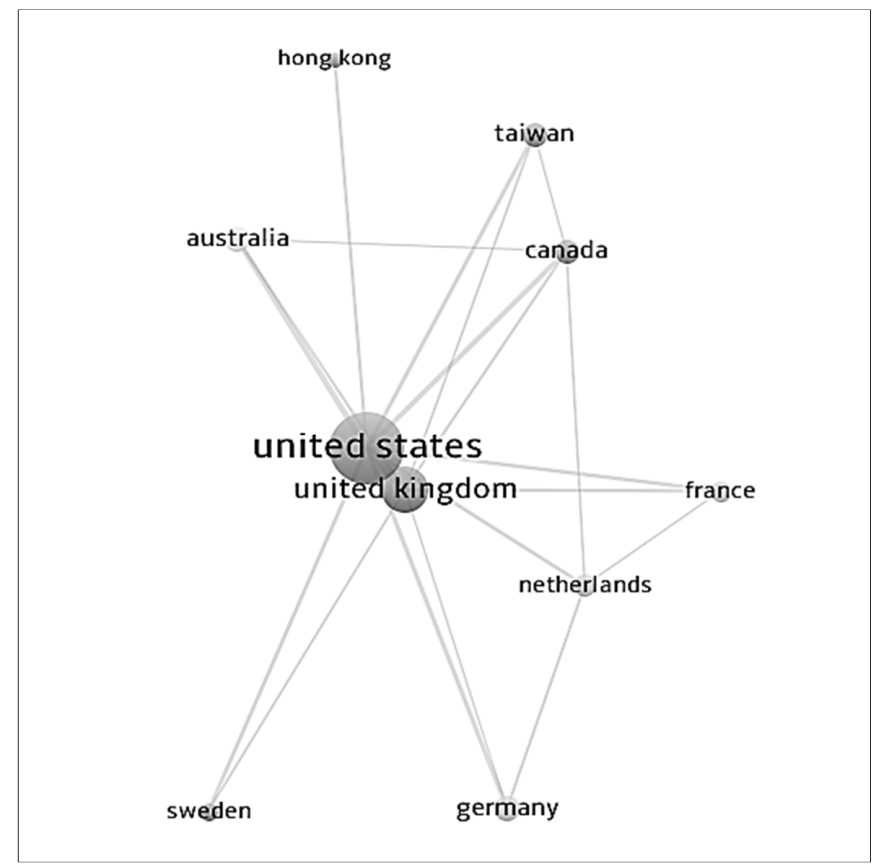

Figure 3 - Network of the Most Influential Countries on "Business Strategy"

The United States and the United Kingdom wield the greatest influence on this theme, since they possess the largest number of publications and the most cited articles and, consequently, contribute the most with research (Scopus, 2017). New bibliometric studies aim to analyse the possible interrelationships among the main countries, institutions and authors (Ferreira et al., 2014). Therefore, Table 2 presents the ten institutions with the best performances on business strategy in the scientific literature. It is worth mentioning that nine of the ten institutions listed in Table 2 are also among the most relevant countries to this topic. 
Table 2 - The Ten Main Institutions on "Business Strategy"

\begin{tabular}{|c|l|l|c|c|c|}
\hline$\#$ & Institution & Country & $\begin{array}{c}\text { Accumulated } \\
\text { citations }(C)\end{array}$ & $\begin{array}{c}\text { Number of } \\
\text { documents }(N)\end{array}$ & $\begin{array}{c}\text { Impact } \\
(\text { C/N) }\end{array}$ \\
\hline 1 & $\begin{array}{l}\text { Harvard } \\
\text { Business School }\end{array}$ & United States & 5,673 & 11 & 515.73 \\
\hline 2 & UC Berkeley & United States & 2,231 & 9 & 247.89 \\
\hline 3 & $\begin{array}{l}\text { Pennsylvania } \\
\text { State University }\end{array}$ & United States & 1,873 & 6 & 312.17 \\
\hline 4 & $\begin{array}{l}\text { University of } \\
\text { Texas at Dallas }\end{array}$ & United States & 1,455 & 5 & 291.00 \\
\hline 5 & $\begin{array}{l}\text { Boston } \\
\text { University }\end{array}$ & United States & 1,389 & 6 & 231.50 \\
\hline 6 & $\begin{array}{l}\text { University of } \\
\text { Michigan State }\end{array}$ & United States & 1,238 & 8 & 75.73 \\
\hline 7 & $\begin{array}{l}\text { University of } \\
\text { Cambridge }\end{array}$ & United Kingdom & 833 & 11 & 53.93 \\
\hline 8 & $\begin{array}{l}\text { University of } \\
\text { Manchester }\end{array}$ & United Kingdom & 809 & 15 & 55.43 \\
\hline 9 & $\begin{array}{l}\text { Erasmus } \\
\text { University } \\
\text { Rotterdam }\end{array}$ & Netherlands & 776 & 14 & 48.50 \\
\hline 10 & $\begin{array}{l}\text { National } \\
\text { University of } \\
\text { Singapore }\end{array}$ & Singapore & 679 & 14 & \\
\hline
\end{tabular}

Only the "National University of Singapore", an institute from Singapore in Southeast Asia, does not belong to the list of the ten most relevant countries related to business strategy, despite presenting a high GDP, high levels of competitiveness and HDI, and expressive investments in research and technology. Pursuant to Zhuang et al. (2013), emerging bibliometric studies should also collect data on and examine the main periodics related to the researched topic. Thus, the ten main and most influential journals in the scientific literature are presented in Table 3.

Table 3 - The Ten Most Influential Journals on "Business Strategy"

\begin{tabular}{|c|l|l|c|c|c|}
\hline$\#$ & Journals (ISSN) & Country & $\begin{array}{c}\text { Accumulated } \\
\text { citations }(C)\end{array}$ & $\begin{array}{c}\text { Number of } \\
\text { documents }(N)\end{array}$ & $\begin{array}{c}\text { Impact } \\
(\text { C/N) }\end{array}$ \\
\hline 1 & $\begin{array}{l}\text { Long Range } \\
\text { Plannin } \\
(0024-6301)\end{array}$ & United Kingdom & 2,345 & 26 & 90.19 \\
\hline 2 & $\begin{array}{l}\text { Academy of } \\
\text { Management } \\
\text { Journal } \\
(0001-4273)\end{array}$ & United States & 1,323 & 7 & 189.00 \\
\hline
\end{tabular}




\begin{tabular}{|c|c|c|c|c|c|}
\hline$\#$ & Journals (ISSN) & Country & $\begin{array}{c}\text { Accumulated } \\
\text { citations }(C)\end{array}$ & $\begin{array}{c}\text { Number of } \\
\text { documents }(N)\end{array}$ & $\begin{array}{c}\text { Impact } \\
(\mathrm{C} / \mathrm{N})\end{array}$ \\
\hline 3 & \begin{tabular}{|l} 
Journal of \\
International \\
Business Studies \\
$(0047-2506)$
\end{tabular} & United Kingdom & 1,238 & 8 & 154.75 \\
\hline 4 & $\begin{array}{l}\text { Academy of } \\
\text { Management } \\
\text { Review } \\
(0363-7425)\end{array}$ & United States & 1,152 & 9 & 128.00 \\
\hline 5 & $\begin{array}{l}\text { Management } \\
\text { Decision } \\
(0025-1747)\end{array}$ & United Kingdom & 1,022 & 17 & 60.12 \\
\hline 6 & \begin{tabular}{|l} 
Journal of \\
Operations \\
Management \\
$(0272-6963)$
\end{tabular} & Netherlands & 896 & 7 & 128.00 \\
\hline 7 & $\begin{array}{l}\text { Journal of } \\
\text { Marketing } \\
(0022-2429)\end{array}$ & United States & 879 & 5 & 175.80 \\
\hline 8 & $\begin{array}{l}\text { Business } \\
\text { Strategy and the } \\
\text { Environment } \\
(0964-4733)\end{array}$ & United States & 873 & 22 & 39.68 \\
\hline 9 & $\begin{array}{l}\text { Strategic } \\
\text { Management } \\
\text { Journal } \\
(0143-2095)\end{array}$ & United States & 822 & 19 & 43.26 \\
\hline 10 & $\begin{array}{l}\text { Industrial } \\
\text { Marketing } \\
\text { Management } \\
(0019-8501)\end{array}$ & Netherlands & 536 & 14 & 38.29 \\
\hline
\end{tabular}

A simple cross-analysis of the ten journals mentioned in Table 3 confirm their presence among the most influential countries regarding business strategy, which also supports the previous interpretation of Table 1 and the analysis made by Tansey, Spillane and Meng (2014). Figure 4 provides the following data on the most scientifically influential articles: title, authors,year of publication, countries of the first authors, number of ISSN, impact factors, SJR, JCR, SNIP (all regarding the year of 2016), average of citations per year (C/N impact) and, finally, the evolution of these citations throughout the years. Figure 5 presents and classifies the most relevant authors of the business strategy literature in descending order, based on the total number of citations accumulated in the period. Figure 5 also shows the authors' citation average, the institutions they belong to, their publication interval, and h-index. Comparative charts with total of absolute and specific publications of each author are reported too. 


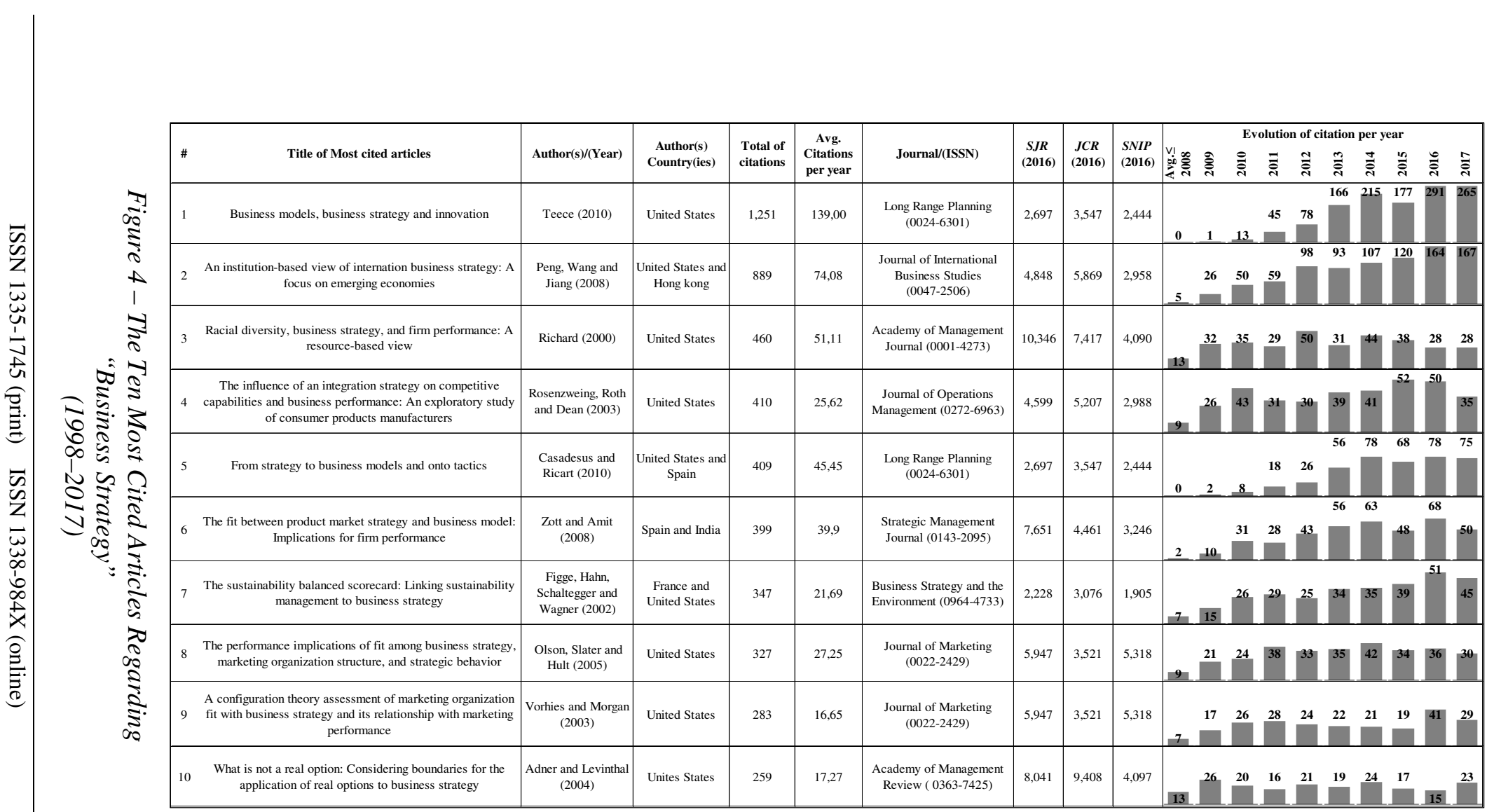




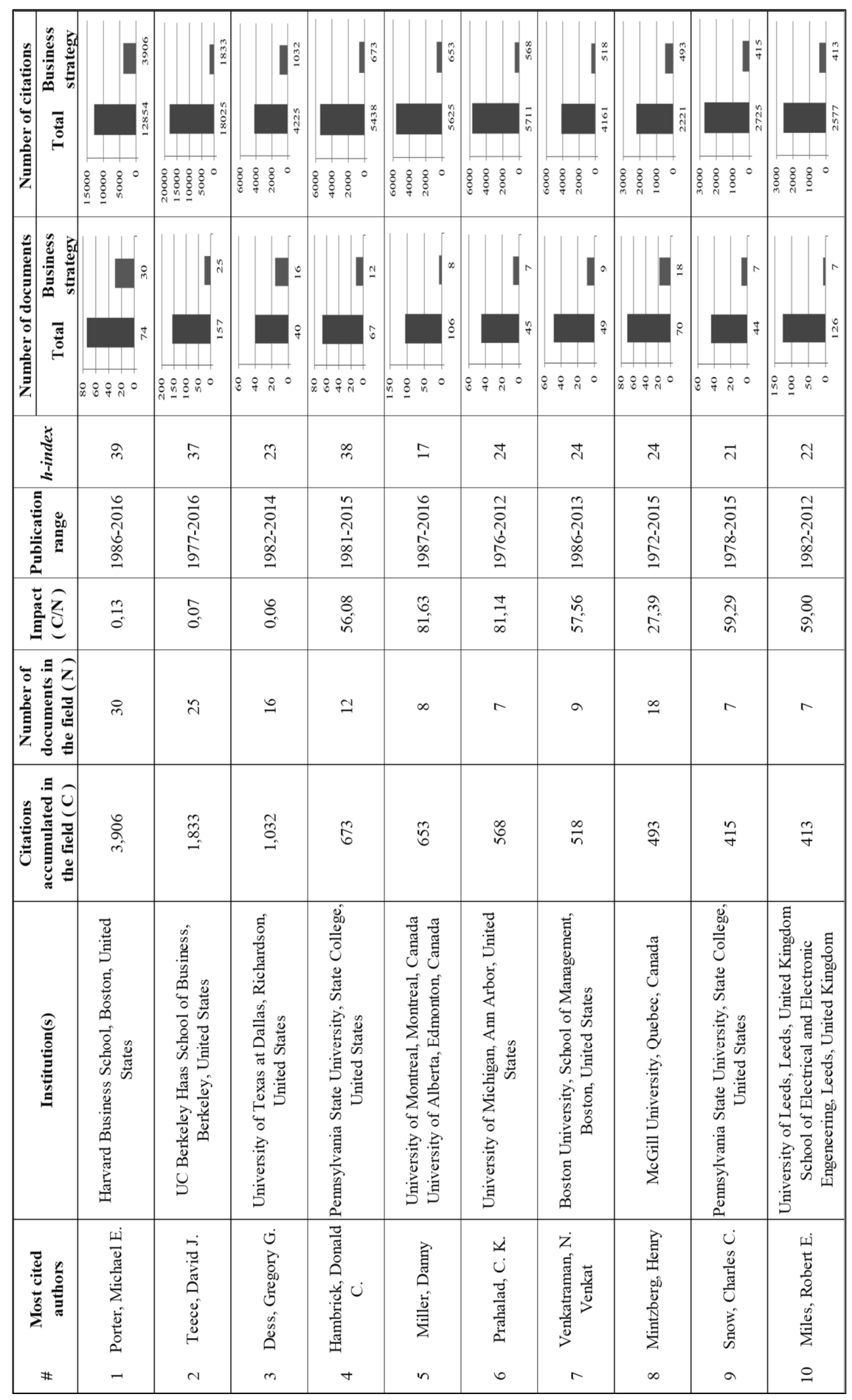

Figure 5 - The Ten Most Cited Authors on “Business Strategy” 
Although the publications' samples represent the period from 1998 to 2017, Figure 4 shows that the ten most cited articles have been published from the year 2000 on. This period coincides with the increase in the number of publications related to the field (Scopus, 2017). It also converges with the findings of Tansey, Spillane and Meng (2014), which outline the insertion of companies in an increasingly globalised market as one of the determining factors for the increase in the number of publications on the subject.

In addition, six of the ten most cited papers were published until 2007. Although they are not recent studies, their analyses and results remain current and relevant both for the academic and business worlds, given the high number of citations they have received over the past 10 years (Scopus, 2017). It is no coincidence that all ten articles in Figure 4 have been published by the ten most influential journals to business strategy.

Analyses of the main authors who published articles and reviews related to business strategy, either mentioning the term in the title, abstract, or keywords, have been carried out in order to identify the most cited authors. It should be emphasised that all of the most cited authors analysed in Figure 5 perform both in the academic environment, as professors and researchers, and in the corporate world, acting as external consultants, a fact that might have influenced the development of studies with great impact for the theme (Scopus, 2017).

The network of authors depicted in Figure 6 has been developed in order to further highlight the impact of the ten most relevant authors on the subject. It evidences the influence that Porter exerts on the theme and on the other analysed authors, since all nine authors cite him in their papers. Thus, it may be concluded that Porter is the most influential author on business strategy. 


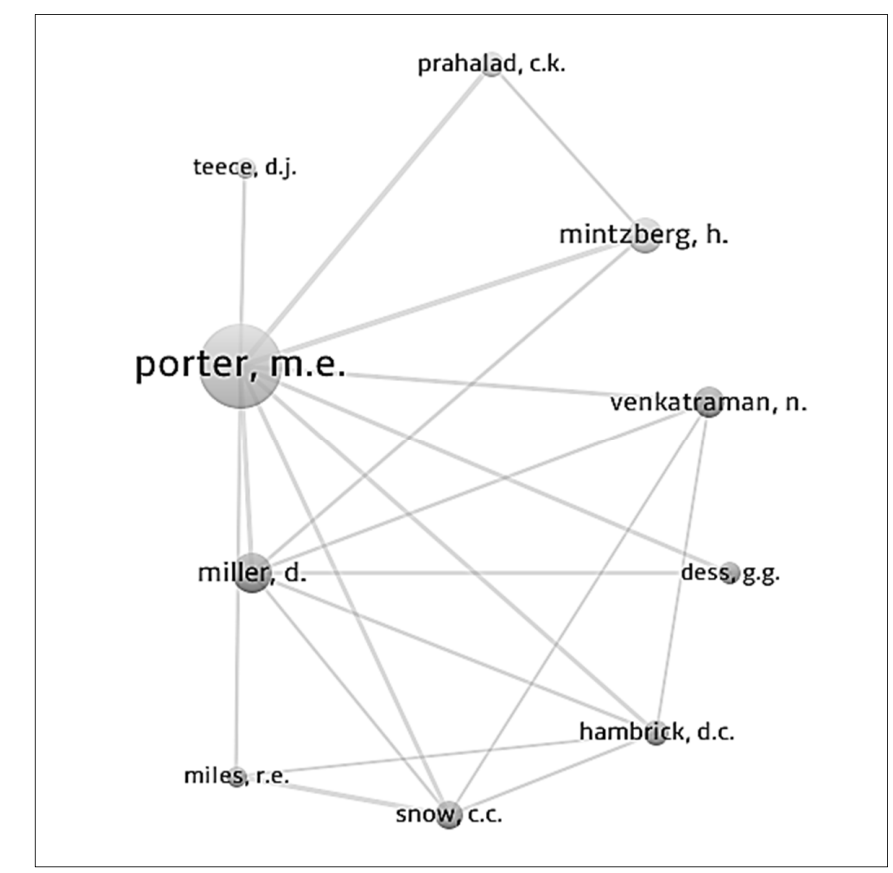

Figure 6-Network Of The Most Cited Authors Regarding "Business Strategy"

\section{MAIN CHARACTERISTICS OF THE ARTICLES AND THE MOST INFLUENTIAL AUTHORS}

In this section, the main relevant characteristics of the most influential articles and authors on business strategy shall be discussed. In order to explain the most important features of the most cited articles on the theme, Table 4 shows the fundamental aspects that these influential papers have presented. These characteristics, or variables, have been gathered based on the bibliometric analyses previously presented in Section 3. The nine variables in Table 4 were considered, to reflect the common aspects making these articles influential and references to the business strategy theme.

Based on the bibliometric parameters presented in Section 3 and on the main characteristics of the most cited articles exhibited in Table 4, it can be inferred that the most influential articles on business strategy have characteristics contemplating some common aspects. First, they belong to prominent international groups (G7 and G20), besides being among the top 25 of the WEF competitiveness ranking and the countries with the highest levels of HDI $(0.800$ to 1). Additionally, they have been published in the top 10 most relevant journals to the topic, while also being produced in partnership with other authors, so that different points of view are contemplated within the researches' findings. 
Table 4 - Main Characteristics of the Most Influential Articles Regarding "Business Strategy"

\begin{tabular}{|c|c|c|c|c|c|c|c|c|c|c|c|c|c|}
\hline \multicolumn{2}{|c|}{ Most cited articles \# } & $1^{o}$ & $2^{o}$ & $3^{o}$ & $4^{o}$ & $5^{\circ}$ & $6^{o}$ & $7^{o}$ & $8^{\circ}$ & $9^{\circ}$ & $10^{\circ}$ & $\begin{array}{c}\text { Total } \\
\text { Amount }\end{array}$ & $\begin{array}{l}\% \text { Total } \\
\text { Amount }\end{array}$ \\
\hline \multicolumn{2}{|c|}{$\begin{array}{l}\text { Top } 10 \text { countries most } \\
\text { relevant to the topic }\end{array}$} & $\mathrm{x}$ & $\mathrm{x}$ & $\mathrm{x}$ & $\mathrm{x}$ & $\mathrm{x}$ & & $\mathrm{x}$ & $\mathrm{x}$ & $\mathrm{x}$ & $\mathrm{x}$ & 9 & 90 \\
\hline \multicolumn{2}{|c|}{ International groups - G20 } & $\mathrm{x}$ & $\mathrm{x}$ & $\mathrm{x}$ & $\mathrm{x}$ & $\mathrm{x}$ & $\mathrm{x}$ & $\mathrm{x}$ & $\mathrm{x}$ & $\mathrm{x}$ & $\mathrm{x}$ & 10 & 100 \\
\hline \multicolumn{2}{|c|}{$\begin{array}{l}\text { Top } 25 \text { of WEF's } \\
\text { competitiveness ranking }\end{array}$} & $\mathrm{x}$ & $\mathrm{x}$ & $\mathrm{x}$ & $\mathrm{x}$ & $\mathrm{x}$ & & $\mathrm{x}$ & $\mathrm{x}$ & $\mathrm{x}$ & $\mathrm{x}$ & 9 & 90 \\
\hline \multirow[t]{3}{*}{ HDI } & $(0.800-1)$ & $\mathrm{x}$ & $\mathrm{x}$ & $\mathrm{x}$ & $\mathrm{x}$ & $\mathrm{x}$ & $\mathrm{x}$ & $\mathrm{x}$ & $\mathrm{x}$ & $\mathrm{x}$ & $\mathrm{x}$ & 10 & 100 \\
\hline & $(0.700-0.799)$ & \multicolumn{12}{|c|}{ - } \\
\hline & $(0.600-0.699)$ & \multicolumn{12}{|c|}{-} \\
\hline \multicolumn{2}{|c|}{$\begin{array}{l}\text { Top } 10 \text { institutions most } \\
\text { relevant to the topic }\end{array}$} & $\mathrm{x}$ & & $\mathrm{x}$ & & & & & & & & 2 & 20 \\
\hline \multicolumn{2}{|c|}{$\begin{array}{l}\text { Top } 10 \text { journals most } \\
\text { relevant to the topic }\end{array}$} & $\mathrm{x}$ & $\mathrm{x}$ & $\mathrm{x}$ & $\mathrm{x}$ & $\mathrm{x}$ & $\mathrm{x}$ & $\mathrm{x}$ & $\mathrm{x}$ & $\mathrm{x}$ & $\mathrm{x}$ & 10 & 100 \\
\hline \multicolumn{2}{|c|}{$\begin{array}{l}\text { Top } 10 \text { authors most cited } \\
\text { on the topic }\end{array}$} & $\mathrm{x}$ & & & & & & & & & & 1 & 10 \\
\hline \multirow{3}{*}{$\begin{array}{l}\text { Type of } \\
\text { publication }\end{array}$} & Single & $\mathrm{x}$ & & $\mathrm{x}$ & & & & & & & & 2 & 20 \\
\hline & Pair & & & & $\mathrm{x}$ & $\mathrm{x}$ & $\mathrm{x}$ & & & $\mathrm{x}$ & $\mathrm{x}$ & 5 & 50 \\
\hline & Group & & $\mathrm{x}$ & & & & & $\mathrm{x}$ & $\mathrm{x}$ & & & 3 & 30 \\
\hline \multirow{2}{*}{$\begin{array}{l}\text { Article } \\
\text { classification }\end{array}$} & Theoretical & $\mathrm{x}$ & & & $\mathrm{x}$ & & & & & $\mathrm{x}$ & $\mathrm{x}$ & 4 & 40 \\
\hline & Empirical & & $\mathrm{x}$ & $\mathrm{x}$ & & $\mathrm{x}$ & $\mathrm{x}$ & $\mathrm{x}$ & $\mathrm{x}$ & & & 6 & 60 \\
\hline
\end{tabular}

Notes: HDI - Human Development Index.

On the other hand, it is not essential to be affiliated to one of the main institutions to have a well-quoted article, nor is it necessary for the researcher to be one of the top 10 most cited authors on that theme. As for the articles' classification, the analyses verified that there is not a prevailing approach for their impact, since the applied research methods varied between theoretical and empirical. In terms of the most important characteristics of the most influential authors to the subject, Table 5 presents the seven variables that were considered while analysing the common aspects of their influence. 
Table 5 - Main Characteristics of Most Influential Authors Regarding "Business Strategy"

\begin{tabular}{|c|c|c|c|c|c|c|c|c|c|c|c|c|c|}
\hline \multicolumn{2}{|c|}{ Most cited authors \# } & 1 & $2^{o}$ & $3^{\circ}$ & $4^{o}$ & $5^{o}$ & $6^{o}$ & $7^{o}$ & $8^{\circ}$ & $9^{\circ}$ & $10^{\circ}$ & $\begin{array}{c}\text { Total } \\
\text { Amount }\end{array}$ & $\begin{array}{l}\% \text { Total } \\
\text { Amount }\end{array}$ \\
\hline \multicolumn{2}{|c|}{$\begin{array}{l}\text { Top } 10 \text { countries most } \\
\text { relevant to the topic }\end{array}$} & $\mathrm{x}$ & $\mathrm{x}$ & $\mathrm{x}$ & $\mathrm{x}$ & $\mathrm{x}$ & $\mathrm{x}$ & $\mathrm{x}$ & $\mathrm{x}$ & $\mathrm{x}$ & $\mathrm{x}$ & 10 & 100 \\
\hline \multicolumn{2}{|c|}{ International groups - G20 } & $\mathrm{x}$ & $\mathrm{x}$ & $\mathrm{x}$ & $\mathrm{x}$ & $\mathrm{x}$ & $\mathrm{x}$ & $\mathrm{x}$ & $\mathrm{x}$ & $\mathrm{x}$ & $\mathrm{x}$ & 10 & 100 \\
\hline \multicolumn{2}{|c|}{$\begin{array}{l}\text { Top } 25 \text { of WEF's } \\
\text { competitiveness ranking }\end{array}$} & $\mathrm{x}$ & $\mathrm{x}$ & $\mathrm{x}$ & $\mathrm{x}$ & $\mathrm{x}$ & $\mathrm{x}$ & $\mathrm{x}$ & $\mathrm{x}$ & $\mathrm{x}$ & $\mathrm{x}$ & 10 & 100 \\
\hline \multirow[t]{3}{*}{ HDI } & $(0.800-1)$ & $\mathrm{x}$ & $\mathrm{x}$ & $\mathrm{x}$ & $\mathrm{x}$ & $\mathrm{x}$ & $\mathrm{x}$ & $\mathrm{x}$ & $\mathrm{x}$ & $\mathrm{x}$ & $\mathrm{x}$ & 10 & 100 \\
\hline & $(0.700-0.799)$ & \multicolumn{12}{|c|}{ - } \\
\hline & $(0.600-0.699)$ & \multicolumn{12}{|c|}{-} \\
\hline \multicolumn{2}{|c|}{$\begin{array}{l}\text { Top } 10 \text { institutions most } \\
\text { relevant to the topic }\end{array}$} & $\mathrm{x}$ & $\mathrm{x}$ & & & & & & & & & 2 & 20 \\
\hline \multicolumn{2}{|c|}{$\begin{array}{l}\text { Top } 10 \text { articles most cited } \\
\text { on the topic }\end{array}$} & & $\mathrm{x}$ & & & & & & & & & 1 & 10 \\
\hline \multirow[t]{3}{*}{$\begin{array}{l}\text { Field of } \\
\text { activity }\end{array}$} & $\begin{array}{l}\text { Professor/ } \\
\text { Researcher }\end{array}$ & \multicolumn{12}{|c|}{ - } \\
\hline & Consultant & \multicolumn{12}{|c|}{-} \\
\hline & Both & $\mathrm{x}$ & $\mathrm{x}$ & $\mathrm{x}$ & $\mathrm{x}$ & $\mathrm{x}$ & $\mathrm{x}$ & $\mathrm{x}$ & $\mathrm{x}$ & $\mathrm{x}$ & $\mathrm{X}$ & 10 & 100 \\
\hline
\end{tabular}

Notes: HDI - Human Development Index.

Once again taking as a basis the previous bibliometric parameters and analyses, it could be determined some common aspects among the most influential authors on business strategy. All of them have been working in the top 10 most influential countries and are part of main international groups (G7 and G20). Besides that, they belong to the top WEF 25 competitiveness rank and represent the countries with the highest levels of HDI (0.800 to 1). Finally, these ten authors work both in the academic and the business areas, which probably adds value to their publications by correlating their theoretical knowledge and their practical experiences in the field. Furthermore, it is not necessary to work for the main institutions, nor have an article among the top 10 most cited articles in order to become an influential author on business strategy.

\section{CONCLUSION}

This article analysed the literature on business strategy through a bibliometric study. The aim of this paper, which was to characterise the most influential articles and authors related to the theme, has been achieved. The article limited the searches and selection of bibliometric parameters to two databases, namely Scopus and Web of Science. Another restriction concerned the mandatory presence of the term "business strategy" in the titles of the articles and reviews. 
Consequently, other articles would probably be included had this limitation not been imposed.

Although bibliometric studies have already been published in managerial and strategic areas and sub-areas, studies contemplating the bibliometric characteristics specifically and solely related to the term "business strategy" have not been found in the international scientific literature. Ergo, the main academic contribution of this article was filling this particular scientific gap. The study's main practical contribution and the main novelty of this research has been the presentation of common aspects considered instrumental for the most influential articles and authors on business strategy.

These analyses shall allow researchers to have a more comprehensive perspective of the subject's state of the art, and serve as benchmarking for other researches related to this and other branches of scientific research. Ultimately, new studies could take advantage of this research when exploring new topics that have not yet been investigated.

\section{ACKNOWLEDGEMENTS}

This work was supported by the Coordenação de Aperfeiçoamento de Pessoal de Nível Superior - Brasil (CAPES) - Finance Code 001, the São Paulo Research Foundation (FAPESP) [grant number 2017/18304-7] and by the Brazilian National Council for Scientific and Technological Development (CNPq) [grant number PQ 312894/2017-1].

\section{REFERENCES}

Abraham, S., 2013. Will business model innovation replace strategic analysis? Strategy \& Leadership [e-journal], 41(2), pp.31-38. doi: 10.1108/10878571311318222.

Agarwal, R., Grassl, W. and Pahl, J., 2012. Meta-SWOT: introducing a new strategic planning tool. Journal of Business Strategy [e-journal], 33(2), pp.12-21. doi: 10.1108/02756661211206708.

Araújo, R., Santos, G., da Costa, J.B. and Sá, J.C., 2019. The quality management system as a driver of organizational culture: An empirical study in the Portuguese textile industry. Quality Innovation Prosperity [e-journal], 23(1), pp.1-24. doi: 10.12776/qip.v23i1.1132.

Barbosa, L.C.F.M., de Oliveira, O.J. and Santos, G., 2018. Proposition for the alignment of the integrated management system (quality, environmental and safety) with the business strategy. International Journal for Quality Research [ejournal], 12(4), pp.925-940. doi: 10.18421/IJQR12.04-09. 
Bravi, L., Murmura, F. and Santos, G., 2018. Manufacturing labs: Where new digital technologies help improve life quality. International Journal for Quality Research [e-journal], 12(4), pp.957-974. doi: 10.18421/IJQR12.04-11.

Bravi, L., Murmura, F. and Santos, G., 2019. The ISO 9001:2015 quality management system standard: Companies' drivers, benefits and barriers to its implementation. Quality Innovation Prosperity [e-journal], 23(2), pp.64-82. doi: 10.12776/qip.v23i2.1277.

Campanario, J.M., 2014. Analysis of the distribution of cited journals according to their positions in the h-core of citing journal listed in Journal Citation Reports. Journal of Informetrics [e-journal], 8(3), pp.534-545. doi: 10.1016/j.joi.2014.04.007.

Carnwell, R. and Daly, W., 2001. Strategies for the construction of a critical review of the literature. Nurse Education in Practice [e-journal], 1(2), pp.57-63. doi: 10.1054/nepr.2001.0008.

Carvalho, F., Santos, G. and Gonçalves, J., 2020. Critical analysis of information about integrated management systems and environmental policy on the Portuguese firms' website, towards sustainable development. Corporate Social Responsibility and Environmental Management [e-journal], 27(2), pp. 10691088. doi.org/10.1002/csr.1866.

Chung, H.K., 2007. Evaluating Academic Journals using Impact Factor and Local Citation Score. Journal of Academic Librarianship [e-journal], 33(3), pp.393-402. doi: 10.1016/j.acalib.2007.01.016.

Coombes, P.H. and Nicholson, J.H., 2013. Business models and their relationship with marketing: A systematic literature review. Industrial Marketing Management [e-journal], 42(5), pp.656-664. doi: 10.1016/j.indmarman.2013.05.005.

Costa, A.R., Barbosa, C., Santos, G. and Alves, M.R., 2019. Six sigma: Main metrics and $\mathrm{r}$ based software for training purposes and practical industrial quality control. Quality Innovation Prosperity [e-journal], 23(2), pp.83-100. doi: 10.12776/qip.v23i2.1278.

Dalby, S., 2007. Regions, strategies and empire in the global war on terror. Geopolitics [e-journal], 12(4), pp.586-606. doi: 10.1080/14650040701546079.

Dutta, S., Lanvin, B. and Wunsch-Vincent, S., 2017. Global Innovation Index 2017: Who Will Finance Innovation? [pdf] Cornell University, INSEAD, the World Intellectual Property Organization. Available at: <http:// www.globalinnovationindex.org> [Accessed 03 May 2018].

Félix, M.J., Silva, S., Santos, G., Doiro, M. and Sá, J.C., 2019. Integrated product and processes development in design: A case study. Procedia Manufacturing [ejournal], 41, pp. 296-303. doi.org/10.1016/j.promfg.2019.09.012. 
Ferreira, M.P., Santos, J.C., Almeida, M.I.R. and Reis, N.R., 2014. Mergers \& acquisitions research: A bibliometric study of top strategy and international business journals, 1980-2010. Journal of Business Research [e-journal], 67(12), pp.2550-2558. doi: 10.1016/j.jbusres.2014.03.015.

Garousi, V. and Mäntylä, M.V., 2016. Citations, research topics and active countries in software engineering: A bibliometrics study. Computer Science Review [e-journal], 19, pp.56-77. doi: 10.1016/j.cosrev.2015.12.002.

Ghemawat, P., 2016. Evolving ideas about business strategy. Business History Review [e-journal], 90(4), pp.727-749. doi: 10.1017/S0007680516000702.

Guerrero-Bote, V.P. and Moya-Anegón, F., 2012. A further step forward in measuring journals' scientific prestige: The SJR2 indicator. Journal of Informetrics [e-journal], 6(4), pp.674-688. doi: 10.1016/j.joi.2012.07.001.

Magretta, J., 2012. Michael Porter answers managers FAQs. Strategy \& Leadership [e-journal], 40(2), pp.11-15. doi: 10.1108/10878571211209305.

Marinho, A., Silva, R.G. and Santos, G., 2020. Why most university-industry partnerships fail to endure and how to create value and gain competitive advantage through collaboration - a systematic review. Quality Innovation Prosperity [e-journal], 24(2), pp. 34-50. doi:10.12776/QIP.V24I2.1389.

de Oliveira, O.J., 2013. Guidelines for the integration of certifiable management systems in industrial companies. Journal of Cleaner Production [e-journal], 57, pp.124-133. doi: 10.1016/j.jclepro.2013.06.037.

Rodrigues, J., de Sá, J.C.V., Ferreira, L.P., Silva, F.J.G. and Santos, G., 2019. Lean management "quick-wins": Results of implementation. A case study. Quality Innovation Prosperity [e-journal], 23(3), pp. 3-21. doi: 10.12776/QIP.V23I3.1291.

Sá, J.C., Amaral, A., Barreto, L., Carvalho, F. and Santos, G., 2019. Perception of the importance to implement ISO 9001 in organizations related to people linked to quality-an empirical study. International Journal for Quality Research [e-journal], 13(4), pp. 1055-1070. doi:10.24874/IJQR13.04-20.

Salavou, H.E., 2015. Competitive strategies and their shift to the future. European Business Review [e-journal], 27(1), pp.80-99. doi: 10.1108/EBR-042013-0073.

Santos, G., Gomes, S., Braga, V., Braga, A., Lima, V., Teixeira, P. and Sá, J.C., 2019. Value creation through quality and innovation - a case study on Portugal. TQM Journal [e-journal], 31(6), pp.928-947. doi: 10.1108/TQM-12-2018-0223.

Santos, G., Murmura, F. and Bravi, L., 2019. Developing a model of vendor rating to manage quality in the supply chain. International Journal of Quality and Service Sciences [e-journal], 11(1), pp.34-52. doi: 10.1108/IJQSS-06-20170058 . 
Santos, G., Rebelo, M., Barros, S., Silva, R., Pereira, M., Ramos, G. and Lopes, N., 2014. Developments regarding the integration of the Occupational Safety and Health with Quality and Environment Management Systems. In: G.I. Kavouras and M.-C.G. Chalbot, eds. 2014. Developments Regarding the Integration of the Occupational Safety and Health with Quality and Environment Management Systems. New York: The Nova Science Publishers. Chapter 6.

Schwab, K. and Sala-i-Martín, X., 2017. The Global Competitiveness Report. [pdf] Geneva: World Economic Forum. Available at: <http://www3.weforum.org/docs/GCR2017-

2018/05FullReport/TheGlobalCompetitivenessReport2017\%E2\%80\%932018.pd f> [Accessed 03 May 2018].

Scopus, 2017. Welcome to Scopus Preview. [online] Available at: <http://www.scopus.com> [Accessed 05 July 2017].

Talapatra, S., Santos, G., Uddin, K. and Carvalho, F., 2019. Main benefits of integrated management systems through literature review. International Journal for Quality Research [e-journal],13(4), pp. 1037-1054. doi: 10.24874/IJQR13.0419.

Tansey, P., Spillane, J.P. and Meng, X., 2014. Linking response strategies adopted by construction firms during the 2007 economic recession to Porter's generic strategies. Construction Management and Economics [e-journal], 32(78), pp.705-724. doi: 10.1080/01446193.2014.933856.

Web of Science, 2017. Clarivate Accelerating innovation. [online] Available at: <http://www.webofknowledge.com> [Accessed 18 February 2017].

Zgodavova, K. and Bober, P., 2012. An innovative approach to the Integrated Management System development: SIMPRO-IMS WEB based environment. Quality Innovation Prosperity [e-journal], 16(2), pp.59-70. doi: 10.12776/qip.v16i2.69.

Zgodavova, K., Bober, P., Majstorovic, V., Monkova, K., Santos, G. and Juhaszova, D., 2020. Innovative methods for small mixed batches production system improvement: The case of a bakery machine manufacturer. Sustainability [e-journal],12(15), pp. 1-20. doi: 10.3390/su12156266.

Zhuang, Y., Liu, X., Nguyen, T., He, Q. and Hong, S., 2013. Global remote sensing research trends during 1991-2010: a bibliometric analysis. Scientometrics [e-journal], 96(1), pp.203-219. doi: 10.1007/s11192-012-0918-z.

Zott, C. and Amit, R., 2008. The fit between product market strategy and business model: implications for firm performance. Strategic Management Journal [e-journal], 29(1), pp.1-26. doi: 10.1002/smj.642. 


\section{ABOUT AUTHORS}

Luís César Ferreira Motta Barbosa - (L.C.F.M.B) Federal Centre for Technological Education Celso Suckow da Fonseca (CEFET-RJ), Maracanã, Rio de Janeiro, Brazil, Department of Production Engineering (DEPRO), Prof., email: luiscesarfmb@gmail.com, Author's ORCID: 0000-0003-4739-4556.

Maria Augusta Siqueira Mathias - (M.A.S.M.) São Paulo State UniversityUNESP, São Paulo, Brazil, Ph.D., e-mail: mas_mathias@yahoo.com, Author's ORCID: 0000-0002-8525-0249.

Manuel Gilberto Freitas Santos - (M.G.F.S.) Design School at the Polytechnic Institute of Cávado Ave (IPCA), Barcelos, Portugal, Prof., e-mail: gsantos@ipca.pt, Author's ORCID: 0000-0001-9268-3272.

Otávio José de Oliveira - (O.J.O.) Production Engineering Post Graduation Programme at São Paulo State University FEG/UNESP, Guaratinguetá - SP, Brazil, Ph.D., e-mail: otaviodeoliveira@uol.com, Author's ORCID: 0000-00025192-3644.

\section{AUTHOR CONTRIBUTIONS}

L.C.F.M.B. - investigation, data curation, original draft preparation, review and editing; M.A.S.M., M.G.F.S. - review and editing; O.J.O. - methodology, data curation, project administration, funding acquisition; L.C.F.M.B, M.A.S.M. visualization, funding acquisition; M.G.F.S., O.J.O. - conceptualization, validation; M.G.F.S., O.J.O. - supervision; L.C.F.M.B, M.A.S.M., M.G.F.S., O.J.O. - formal analysis, resources.

\section{CONFLICTS OF INTEREST}

The authors declare no conflict of interest. The funders had no role in the design of the study; in the collection, analyses, or interpretation of data; in the writing of the manuscript, or in the decision to publish the results.

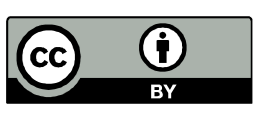

(C) 2020 by the authors. Submitted for possible open access publication under the terms and conditions of the Creative Commons Attribution (CC-BY) license (http://creativecommons.org/licenses/by/4.0/). 